\title{
The relationship of wolf recovery to habitat conservation and biodiversity in the northwestern United States
}

\author{
Steven H. Fritts ${ }^{*, a}$, Edward E. Bangs ${ }^{\mathrm{a}}$, James F. Gore ${ }^{\mathrm{b}}$ \\ ${ }^{a}$ US Fish and Wildlife Service, Ecological Services, 100 N. Park, Suite 320, Helena, MT 59601, USA \\ ${ }^{\mathrm{b}}$ US Forest Service, Wildlife and Fisheries, 14th and Independence Ave, P.O. Box 96090, Washington, DC 20090-6090, USA
}

\begin{abstract}
Gray wolves were systematically and fervently eliminated from the northwestern United States between the mid-1800s and early 1900s. Wolves disappeared from lower elevations first and generally persisted longer in more remote, mountainous areas. Preservation of large tracts of public land, primarily for commodity use, at the turn of the century, had the unforeseen effect of allowing conditions for wolf recovery to occur later. Improving attitudes toward the species and the recovery of ungulate prey populations from their turn of the century lows are the proximate factors making wolf recovery possible in areas with vast public lands. Planners for wolf recovery in the Northern Rockies identified three areas for wolf recovery, northwestern Montana, central Idaho, and the Greater Yellowstone area, because they consisted primarily of national parks, designated wilderness, and national forests. Those areas had previously been designated as public lands largely because they were too unproductive for agriculture; they consist in part of high elevation habitat that supports relatively few prey for wolves in winter. So far, recolonizing wolves have settled in lower elevation habitats where deer and elk are most abundant. Since private lands are most often in these lower elevations, they may be more important to the recovery and maintenance of viable wolf populations than was earlier envisioned. The negative symbolic nature of the wolf was a major factor in its eradication and continues to be a major factor in considerations of reintroduction and natural recolonization; the newer positive symbolic nature of the animal will ultimately facilitate its return and contribute indirectly toward long-term conservation of wild spaces and biodiversity in North America.
\end{abstract}

\section{Introduction}

Our objective is to examine the relationship between gray wolf (Canis lupus) recovery and habitat conservation and biodiversity in the northwestern US. Previous studies have predicted direct impacts of wolf recovery on big game hunting, livestock production, local economies, and recreational opportunities (Yellowstone National Park et al., 1990; Varley and Brewster, 1992). Here, we focus on what could be the long-term impacts of wolf recovery on ecosystem integrity and biodiversity. The discussion is limited to northwestern states where recovery is now occurring or expected, although recovery programs are in

*Corresponding author: Tel. (406) 449-5225. progress in the upper Midwest and the southwest, and a red wolf (Canis rufus) recovery program is proceeding in the southeastern US.

Probably no human-animal relationship has been so strained throughout recorded history as that with wolves. For the most part, humans have been stridently unwilling to share the landscape with this intelligent social predator that once ranged over most of the Northern Hemisphere. Perhaps the fortunes of no other species have been so sensitive to human perceptions and attitudes. In our experiences with recovery activities in the northwestern US and in previous experiences with research and management of wolves, we have been constantly reminded that in the minds of humans the wolf is much more than just an animal. Different people see the wolf entirely differ- 
ently because of its strong symbolic nature and cultural traditions. Different cultures have viewed the wolf uniquely, ranging from reverence by early native Americans to fear and hatred, with negative religious connotation by Europeans during the Middle Ages and by American colonists (Lopez, 1978). In Europe, the wolf was persecuted in many parts of the continent, the extent of which depended on the rclationships of people with their environment (Boitani, 1993). The most negative of attitudes developed in parts of Europe where the human ecological type was nomadic shepherds, while sedentary crop and livestock growers were more ambivalent, and hunters and warriors had positive views of the wolf (Boitani, 1993). Unfortunately for the wolf, most European settlers in North America were from places and backgrounds where attitudes were most negative (Oakley, 1986). Thus, current North American attitudes were shaped primarily by these European attitudes, where wolves were portrayed in myths, legends, and fables as strong negative symbolic figures.

Prior to colonization by European man, the gray wolf occupied almost all of North America (Young, 1944). Twenty-four subspecies were originally named, but taxonomists now think there were only five or fewer subspecies in North America (Nowak, 1983; R.M. Nowak, personal communication, 1993). Current indications are that genetic variation across the wolf's range is not great (Wayne et al., 1992), most likely because of the mobility of members of the species across great distances and different habitat types (Brewster and Fritts, 1993). Dispersal of up to $880 \mathrm{~km}$ has been documented (Fritts, 1983). Within its vast American range, the wolf occupied essentially every type of habitat except for the highest mountains and driest deserts. The wolf is a true 'generalist' in its habitat requirements, allowing the species to have at one time the broadest distribution of any land mammal except man (Nowak, 1983).

Wolves will prey on whatever wild ungulates happen to occupy their habitat (Mech, 1970). In the Great Plains and mountains of Montana, Wyoming, and Idaho, bison (Bison bison), elk (Cervus elaphus), mule deer (Odocoileus hemionus), white-tailed deer (Odocoileus virginianus), and moose (Alces alces) were common prey. Some wolves also kill domestic animals when available. As a top carnivore, wolves play a major role in food chains, energy flow, and nutrient cycles. Their kills are scavenged by many species of mammals and birds. Wolf densities are higher in areas of higher ungulate biomass (Fuller, 1989), which is dependent on plant productivity and snow depth. In the Northwest this is strongly related to elevation and moisture availability. Because of this relationship, we think it is reasonable to assume that pre-settlement wolf densities in the Northwest were higher in the plains, foothills, and large river valleys than in the mountains, as has been implied or found by a number of other authors (Kaminski and Boss, 1981; Gunson, 1983; Tompa, 1983; Kaminski and Hansen, 1984; Pletscher et al., 1991).

\section{Wolf eradication}

Early explorers to the Northern Rockies and Pacific Northwest described an abundance of ungulates and predators. Wolves were frequently mentioned in the journals of explorers (DeVoto, 1953; Schullery and Whittlesey, 1992). The land and its wildlife soon came under heavy exploitation, and the landscape changed in epic proportions. From 1850 to 1870 , overharvesting of big game for hides and choice pieces of meat and the resulting abundance of large carcasses, apparently led to a temporary increase of wolves in Montana (Curnow, 1969). By 1884, bison in Montana were eliminated. By the 1910 s, populations of elk, deer, bighorn sheep (Ovis canadensis), and pronghorn (Antilocapra americana) were reduced by unregulated market and subsistence hunting to remnant groups (Mussehl and 
Howell, 1971; Bryant and Maser, 1982).

Between 1850 and 1886, cattle numbers increased as bison disappeared from grasslands and native Americans were displaced. Grazing on open range was widespread by the mid1880s. Between 1867 and 1890 the number of cattle in Montana increased from 67000 to 1.1 million and sheep from 300000 to 2.2 million (Montana Agricultural Statistics Service, 1992). As the numbers and distribution of large wild ungulates were reduced, large predators, including wolves, increasingly turned to livestock; depredation on cattle was perceived to be a serious problem and became the strongest rationale for killing wolves (Curnow, 1969). During that era, societal views of the wolf were almost unanimously negative (Fogleman, 1989). Most early settlers saw the animal as the embodiment of a godless "howling wilderness' to be driven back in the name of civilization. Hardly anyone would have suggested that land suitable for agriculture should be shared with any wild animal, let alone the wolf. Even the great conservationist Theodore Roosevelt condemned the wolf, calling it the "beast of waste and desolation" (Dunlap, 1988 ). The wolf, along with a few other large carnivores, came to symbolize the wilderness-then an extremely negative symbol. Wolves were even persecuted in national parks, natural areas set aside for the benefit of future generations.

Wolves were killed by shooting, poisoning, den hunting, trapping, and snaring (Young, 1944; Lopez, 1978). Bounties were offered by state and local governments and livestock associations. An estimated 100000 wolves per year were killed in Montana from 1870 to 1877 , and government bounties were paid on over 80000 wolves in that state between 1883 and 1918 (Curnow, 1969). Many of these were probably coyotes (Canis latrans). About 1915, the federal government became involved in the effort to achieve wolf eradication via establishment of the Division of Predator and Rodent Control within the Biological Survey (Dunlap, 1988). Wolves had essentially disappeared from the Northern Rockies by the 1920s1930s. They had been eliminated from Yellowstone National Park (YNP), Montana, and Idaho by the 1930s (Curnow, 1969; Weaver, 1978; Kaminski and Hansen, 1984). Wolves had been reduced to small numbers in Washington by 1859 and were eradicated between 1915 and 1929 (Laufer and Jenkins, 1989). The story was much the same in western Canada. For decades, the southern edge of the species' breeding range in western North America was well north into British Columbia and Alberta, although much suitable habitat existed further south in Canada and the US. Little was learned or recorded about the biology of the species in the northwestern US during the eradication period because few cared. Most records of the time dealt with wolf control and stories of the particularly hard-to-catch individuals that preyed on livestock (Young, 1944). Few of the new residents of the northwestern US expressed any desire to share their newly tamed landscape with wolves again. Other predators suffered the same exploitation as wolves; the persecution of wolves was just more long-lived and complete.

Societal views about the use of public lands and the role of agriculture and other commodity interests (Burger, 1978) was a major factor in wolf eradication; a change in those views would play a major role in future attempts to restore the species. Actually, loss of wildlife, including the wolf in the Northwest, was more a result of persecution than loss of places for them to live. Wolves could have survived in the wooded mountains as they did in the forests of northeastern Minnesota if they had not been so vigorously pursued with poison in mountainous areas of summer livestock production. 


\section{Wolf restoration}

\subsection{Factors allowing restoration: attitude, habitat, legislation}

Attitudes toward the wolf slowly improved (Kellert, 1985; Bath, 1991), reflecting a general change in outlook on wildlife, the environment, and use of public lands. Such changes in attitudes and social values ultimately led to changes in federal legislation (cf. Dunlap, 1988; Keiter and Holscher, 1990). Homesteading, the conversion of public lands into private lands, reversed itself during the 1920 s and 1930s (Great Depression) and new values slowly began to be placed on wild spaces. In the early 1900 s, laws were passed to protect various game animals. By the 1960 s these attitudes were extended to various predators, and bounties were eliminated on mountain lions (Felis concolor), coyotes, and, in Canada and Alaska, wolves. Also, by the late 1960 s, there were calls to restore wolves to YNP (Mech, 1991 ). Habitat for the wolf in the region steadily improved as modern wildlife management allowed ungulate populations to rebound from their turn of the century lows (cf. Mussehl and Howell, 1971). Today, ungulate populations throughout the Northern Rocky Mountains are at their highest levels in nearly 100 years.

Domestic sheep inventories declined in Montana from 3.9 million in 1930 to 0.7 million in 1992, while cattle increased from 1.2 to 2.5 million. A trend toward fewer people in rural areas occurred: Montana's farm population declined from 228000 in 1920 to 90000 in 1970 , while average farm size has more than doubled over the past six decades, and total land in farms declined slightly (Montana Agricultural Statistics Service, 1992). A large portion of the Northwest was under the management of federal agencies long before wolf restoration was contemplated. Federal and private land ownership in the respective states is: Montana, 29\% and 35\% (Conner and
O'Brien, 1993 ); Idaho, $64 \%$ and $31 \%$ (Idaho Department of Commerce, 1992); Washington, $30 \%$ and $55 \%$ (Dunford and Zander, 1983 ); Wyoming, $51 \%$ and $42 \%$ (Wyoming Department of Administration and Fiscal Control, 1987).

Legal protection and a federal mandate to restore wolves came with passage of the Endangered Species Act of 1973 (ESA) (16 U.S.C. 1531 et seq.). A Recovery Team for the Northern Rockies evaluated Montana, Idaho, and Wyoming for areas that could support "viable, self-sustaining populations" of wolves (US Fish and Wildlife Service (USFWS), 1987). The criteria included:

(1) the presence of an adequate prey base on a year-round basis; (2) at least $7770 \mathrm{~km}^{2}$ of contiguous designated wilderness, national parks, and adjacent public lands; (3) a maximum of $10 \%$ private land ownership; (4) the absence, if possible, of livestock grazing; (5) isolation from populated or heavy-use recreational areas that would allow protection of ten breeding pairs of wolves from human disturbance.

Note that the criteria involved both protection of human economic activities from wolves and wolves from persecution by humans. The recovery areas identified were northwestern Montana, central Idaho, and the greater Yellowstone area (USFWS, 1987 p. 23 ) (Fig. 1). Not surprisingly, these areas are also identified for the recovery of another large predator, the grizzly bear (Ursus arctos). The proven ability of these areas to support high densities of wolves was not among the criteria of selection. As alluded to earlier, these areas likely harbored fewer wolves historically because of their higher elevations and lower carrying capacity for prey. Plains and large river valleys in Montana, Idaho, Wyoming, and Washington probably supported the highest densities of large ungulate prey and wolves, but now are mostly in residential, municipal, and agricultural use. In short, the wolf is now expected to live in 


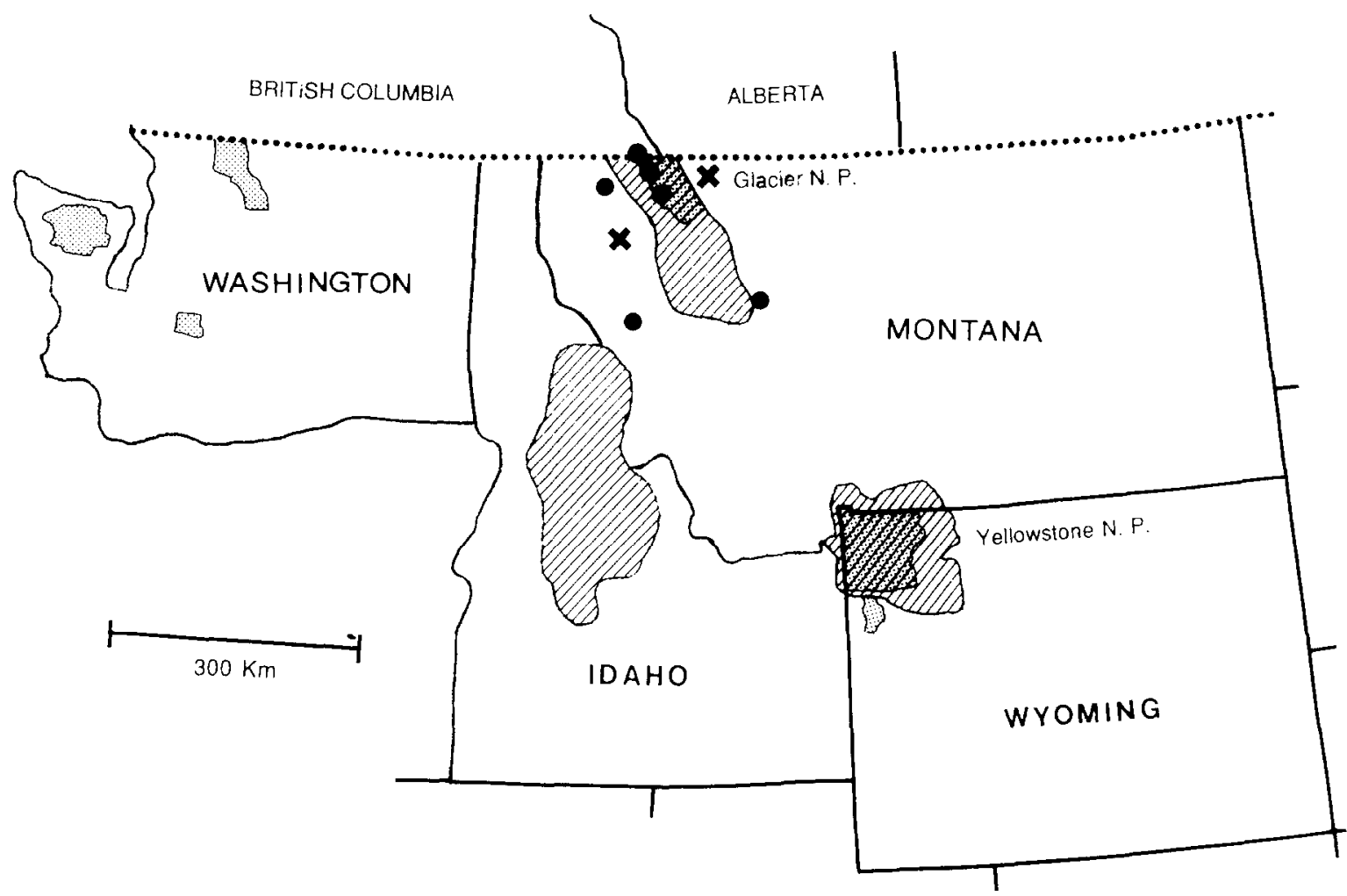

Fig. 1. Northwestern United States showing three wolf recovery areas that were identified in the Northern Rocky Mountain Wolf Recovery Plan (cross-hatching). Locations where wolf packs lived in 1993 (dots) and where other packs had previously become established but were removed because of depredations on livestock are also indicated (X). National Parks in the four-state area are indicated by shading.

places that were undesirable for humans.

The Recovery Plan for the Northern Rockies defined recovery as ten breeding pairs of wolves (about 100 individuals) in each of the three separate areas for a minimum of three consecutive years (USFWS, 1987, p. 12). Subdivision of the area-wide population together with the ability of wolves to move between recovery areas was to provide a safeguard against a catastrophic event decimating wolves in any one area. Natural recovery by wolves moving southward from Canada was to be promoted in northwestern Montana and for a 5 year monitoring period in central Idaho, whereas a reintroduction was recommended to Yellowstone. A recovery plan has not yet been written for Washington, although wolves are beginning to naturally recolonize there.

\subsection{Recovery progress}

Primarily as a result of favorable wolf management actions in Canada, wolf populations increased and finally colonized south of the international border in Montana. Single wolves showed up in the 1970s in a number of northwestern states (Ream and Mattson, 1982; Nowak, 1983; USFWS, 1987). All were thought to be dispersers from British Columbia and Alberta. Breeding occurred in Glacier National Park (GNP) in Montana in 1986-for the first time in the western US in half a century (Ream et al., 1989). In 1988, the USFWS established a proactive wolf recovery program in Montana, Idaho, and Wyoming, and shortly afterward in Washington (Bangs, 1991; Fritts, 1991 ), with strong emphasis on public educa- 
tion about wolves. By 1993, five radio-collared wolf packs were being monitored in northwestern Montana in addition to another that ranges both sides of the international border. The wolf population in northwestern Montana and adjacent southeastern British Columbia had grown to about 59 by August 1992. Most wolves live in and near GNP in the North Fork of the Flathead River, but an increasing number of wolves are surviving outside that area in Montana (Fritts et al., 1993). Some lone wolf activity occasionally occurs in Idaho and Yellowstone, but breeding has still not been confirmed. In 1991, a pair of wolves was videotaped in Idaho, and shortly thereafter one was found poisoned. In 1992, a much publicized wolf-like animal was filmed in central YNP, and a wolf was shot just south of the park. The latter animal apparently was a disperser from northwestern Montana. Wolves apparently have also colonized Washington in recent years, but none have been captured and radiomonitored.

\subsection{Current habitat for wolves}

Colonizing wolves in Montana have settled in large river valley systems, evidently because of the abundance of deer and easier travel. Four of seven known packs (two of which were removed because of livestock depredations) established outside the Montana recovery area where private land is more common. All Montana packs have spent part of their time on private land, and most current pack territories encompass a mix of public and private land. Even packs living essentially within GNP are at its western edge and visit parcels of private land and the Flathead National Forest outside the park boundary. Those packs routinely follow the drainage which comprises the western edge of the park $(1200 \mathrm{~m})$, especially in winter (Pletscher et al., 1991; Rcam et al., 1991), causing them to live continually at the edge of public lands. Likewise, wolves in and south of Banff Park, Alberta $(200 \mathrm{~km}$ north of the US border) use lower elevations more extensively. Among thousands of radio-fixes on wolves in that area, some $95 \%$ were below $1800 \mathrm{~m}$, with snow depth, aspect, and slope all thought to be influencing the use of habitat (P. Paquet, personal communication, 1993 ).

Within a national park, designated wilderness, or national forest, extensive use of drainages in lower elevation areas poses no particular problem. IIowever, if most wolves outside protected areas and within human-inhabited areas follow that pattern, the number of wolfhuman conflicts may be greater, the number of wolves killed illegally or accidentally higher, and recovery more difficult to accomplish than otherwise anticipated. Extensive use of drainage systems will bring wolves into conflict with livestock and increase their encounters with humans, and therefore result in more mortality from illegal killing and from agency wolf control in response to depredations on livestock. Three packs have already depredated on livestock on private land in Montana, and since 1980 it has been necessary to control 17 problem wolves (Bangs et al., 1993).

Much remains to be learned about where wolves will try to live in the Northern Rockies and Pacific Northwest and how well humans will tolerate them. However, current indications are that more remote and pristine areas of high elevation will at least occasionally be forsaken for areas of high prey density which will bring wolves into proximity with humans. Portions of national parks and designated wilderness in the Northern Rockies may not be used by wolves owing to high elevation, very steep terrain, snow depth, and poorer habitat quality for seasonal use by ungulates (cf. Koth et al., 1990). This is not to say that large expanses of public land are unimportant to wolf recovery, as they are absolutely essential for that purpose. For example, a portion of northcentral YNP is expected to have one of the highest wolf densities ever recorded because of locally high ungulate densities (Yellowstone National Park et al., 1990). However, strategic 
parcels of private land in proximity to public lands may be more important than acknowledged in recent deliberations about wolf recovery. Dealing with dispersing wolves, many of which will try to occupy lower elevation private land, may be a continuing challenge.

The Northern Rocky Mountain Wolf Recovery Team recognized the potential importance of private land for wolves. One of the tasks in the recovery plan (USFWS, 1987, p. 38 ) is to "identify private lands that may be necessary for survival and recovery of the wolf and secure management authority through development of Memorandums of Agreement, conservation easements, or cooperative agreements or by purchase, exchange or lease. Areas such as key ungulate winter ranges that may be threatened by subdivision and development should be considered high priority for such actions. Condemnation of private lands would do little to stimulate support for wolf recovery and would not be considered a means of achieving management authority over essential habitat." Another option for encouraging the use of private or other non-federal lands for wolf recovery, which was not included in the recovery plan, is the development of a Habitat Conservation Plan (HCP) under Section 10 of the ESA. This process would allow the USFWS to permit a certain amount of incidental taking of wolves on non-federal lands in situations where non-federal actions may harm or harass wolves. In exchange for this permit, the non-federal party would implement an HCP that minimizes the take as much as practicable. These measures are among the few mechanisms that the USFWS has available under the ESA to intervene in actions regarding wolves on nonfederal lands.

Wolf recovery poses a dilemma for the agencies that manage public lands in the Northwest. The conservation-oriented public desires to protect what it perceives to be primary wolf habitat (wilderness) from human disturbance. Wolves, however, require little in the way of land-use restrictions to promote their recovery so long as people are not killing too many of them. Moreover, concerns about landuse restrictions are one of the primary reasons given for opposition to wolf recovery (USFWS, 1993). To consumptive users of public lands concerned about restrictions, the wolf is strongly symbolic of big government impositions and the influence of 'outsiders', whereas to conservationists it symbolizes wildness and is viewed as a forerunner of more enlightened use of public lands. Notwithstanding the fact that the national public and even the majority of the local public in the Northern Rockies favors wolf recovery, strong opposition still exists and those individuals, usually being local, have a disproportionate potential to prevent wolf recovery through illegal killing.

Section 7 of the ESA functions as a legal safeguard against federal actions that may jeopardize the continued existence of listed species by requiring that federal agencies consult with the USFWS before initiating or allowing activities that might adversely affect those species. Examples of pertinent Section 7 issues are road building, mining, grazing, logging, and control of wolves for livestock depredations on public land, disturbance in the vicinity of den and rendezvous sites, and use of certain predator control techniques (primarily poisons) where wolves may exist. Some individuals and conservation organizations seek to use any tool available for reducing what they perceive as habitat-degrading activities in wild areas. Section 7 is an important tool to help protect ecosystems upon which listed species depend, and has been used extensively and legitimately for other species, including the grizzly bear, which is quite sensitive to human disturbances in the environment and has a much lower reproductive potential than wolves. Strict implementation of similar measures for wolves without obvious biological justification would create strong resentment among local publics which, we believe, would result in more wolves being illegally killed, thus offsetting any advantage to the wolf 
gained through restrictions (Tucker and Pletscher, 1989; Tucker et al., 1990). The strategy of the USFWS in consultations with other agencies to date has been to minimize the use of restrictions, believing that approach is in the best interest of wolf recovery, while recommending maintenance of ungulate populations. Only two restrictions are in place.

(1) A $1.6 \mathrm{~km}$ ( 1 mile) area around dens and initial rendezvous sites may be protected from intensive human use between 15 March and 1 July to protect these areas from disturbances that could jeopardize pup survival by causing them to be moved prematurely.

(2) Animal Damage Control personnel may not use non-selective controls, i.e. poison, to control predators in areas occupied by wolves, primarily because of Environmental Protection Agency toxicant label registrations affecting their use around endangered species (Bangs, 1991).

No other restrictions are planned for public lands in the Northern Rockies unless illegal killing makes them necessary. Therefore, implementation of land-use restrictions in the name of wolf recovery under Section 7 of the ESA should not be a significant factor in overall habitat conservation and biodiversity.

\section{Conclusions}

People have varying perceptions of what comprises wolf habitat. In reality, suitable habitat for the wolf simply consists of two major components: (1) ungulate prey, and (2) freedom from excessive human persecution. So far in recent American history, the latter has required large wild spaces for wolves because of the negative attitudes of humans: the more negative the attitudes, the more wild space necessary to keep human-wolf contacts below a critical level. Tolerance of the wolf has increased dramatically in the past half century and the species now has many advocates, though opposition is still strong among rural residents and livestock producers. In the fu- ture, the public will be more willing to allow wolves to live in close proximity than at any time in recent history. Some may even welcome wolves nearby, enjoying occasional howling and getting a rare glimpse of the predators. Though often thought of as a species of remote wilderness areas, wolves can and do live near humans. Doing so, however, increases their chance of being illegally killed, or being controlled because of their depredations on domestic animals.

Topography and elevation may be major determinants of wolf distribution in the Northwest. The tendency to try to live in low elevation areas with relatively high prey density suggests that certain parcels of private land may be important to wolves. The provision of habitat for the wolf is dependent on wise ungulate management, which in part equates to good habitat management for elk, deer, bison, and moose, all of which tend to overwinter in low elevation areas with less snow cover. Because private holdings may have particularly high value for wolves and other wildlife, wildlife resource agencies should be positioned to acquire these lands if landowners should choose to sell. Such action would help to knit back together fragmented landscapes and benefit a variety of species.

The charisma and symbolism of the wolf will make it an effective symbol for wildlife and habitat conservation. In the future, the public will probably want to ensure the welfare of wolves by guaranteeing they have ample habitat. Wolves have already proven to be an effective symbol for marketing various other agendas and products. Attention to the size of areas used by wolves and their need for large relatively undeveloped areas to avoid conflicts with humans will, in the long run, also aid in the conservation of habitat for other wildlife. Therefore, the return of wolves to some of America's wildlands will be a force favoring long-term habitat conservation and biological diversity, and thus be consistent with the broader purpose behind the Endangered Spe- 
cies Act of 1973, as amended: "to provide a means whereby the ecosystems upon which endangered species and threatened species depend may be conserved" (16 U.S.C. 1531 et seq.). In previous times, the wolf was a powerful negative symbol in the American West, and that symbolism was largely responsible for the animal's demise. It is the emerging favorable symbolism of the wolf that is largely responsible for its return. We believe that it is mostly through wolves' symbolic nature that wolf recovery will contribute toward long-term conservation of wild spaces and biodiversity in northwestern America.

Future wolf recovery looks fairly bright, primarily because of the animal's adaptive nature and ability to live in marginally productive areas that are unsuitable for agriculture and other intensive land uses by humans (though probably at lower population densities ). Species that strictly require highly productive landscapes or habitat may not be as fortunate. Large predators will have to subsist on whatever large blocks of land that humans are willing to forego for them, and the extent of that allocation is determined by economics and the values and priorities of society.

Finally, we would do well to remember that it is not by design, but more by accident that enough wild spaces were preserved to make the recovery of wolves possible. The lesson we should learn-once again-is that all of the long-term benefits of habitat and ecosystem preservation cannot possibly be anticipated.

\section{Acknowledgments}

The authors appreciate the assistance and comments for manuscript improvement provided by W.G. Brewster, J.A. Fontaine, J. Haas, D.H. Harms, S. Jackson, and P. Paquet. We also thank the personnel of the Wolf Ecology Project at the University of Montana for their pioneering work on wolf ecology in the Northern Rockies.

\section{References}

Bangs, E., 1991. Return of a predator: wolf recovery in Montana. West. Wildl., 17: 7-13.
Bangs, E.E., Fritts, S.H., Harms, D.R., Fontaine, J.A., Jimenez, M.D., Brewster, W.G. and Niemeyer, C.C., 1993. Control of endangered gray wolves in Montana. In: Proceedings of the 2nd North American Wolf Symposium, 2427 August 1992, in press.

Bath, A.J., 1991. Public attitudes in Wyoming, Montana and Idaho toward wolf restoration in Yellowstone National Park. Trans. North Am. Wildl. Nat. Resour. Conf., 56: $91-$ 95.

Boitani, L., 1993. Ecological and cultural diversities in the evolution of wolves-humans relationships. In: Proceedings of the 2nd North American Wolf Symposium, 24-27 August 1992, in press.

Brewster, W.G. and Fritts, S.H., 1993. Taxonomy and genetics of the gray wolf, Canis lupus in North America. In: Proceedings of the 2nd North American Wolf Symposium, 24-27 August 1992, in press.

Bryant, L.D. and Maser, C., 1982. Classification and distribution. In: J.W. Thomas and D.E. Toweill (Editors), Elk of North America: Ecology and Management. Wildlife Management Institute and Stackpole Books, Harrisburg, PA, pp. 1-59.

Burger, G.V., 1978. Agriculture and wildlife. In: H.P. Brokaw (Editor), Wildlife and America, Council on Environmental Quality, Washington, DC, pp. 89-107.

Conner, R.C. and O'Brien, R.A., 1993. Montana's Forest Resources. Resource Bulletin 81. US Department of Agriculture, Forest Service, Intermountain Research Station, Ogden, UT, 96 pp.

Curnow, E., 1969. The history of the eradication of the wolf in Montana. M.S. Thesis. University of Montana, Missoula, MT, $99 \mathrm{pp}$.

DeVoto, B., 1953. The Journals of Lewis and Clark. Houghton Mifflin, Boston, MA, 504 pp.

Dunford, R.W. and Zander, D., 1983. Public lands in Washington, Statistical Summary. Res. Bull. XB 0931, Agricultural Research Center, Washington State University, Pullman, WA, $13 \mathrm{pp}$.

Dunlap, T.R., 1988. Saving America's Wildlife. Princeton University Press, NJ, $222 \mathrm{pp}$.

Fogleman, V.M., 1989. American attitudes toward wolves: a history of misperception. Environ. Ethics, 10: 63-94.

Fritts, S.H., 1983. Record dispersal by a wolf from Minnesota. J. Mammal., 64: 166-167.

Fritts, S.H., 1991. Wolves and wolf recovery efforts in the northwestern United States. West. Wildl., 17: 2-6.

Fritts, S.H., Bangs, E.E., Fontainc, J.A., Brewster, W.G. and Gore, J.F., 1993. Restoring the wolf to the Northern Rockies of the United States. In: Proceedings of the 2nd North American Wolf Symposium, 24-27 August 1992, in press.

Fuller, T.K., 1989. Population dynamics of wolves in northcentral Minnesota. Wildl. Monogr., 105: 1-41.

Gunson, J.R., 1983. Status and management of wolves in Alberta. In: L.N. Carbyn (Editor), Wolves in Canada and Alaska: Their Status, Biology, and Management. Rep. Ser. No. 45, Canadian Wildlife Service, Ottawa, Canada, pp. 25-29.

Idaho Department of Commerce, 1992. County Profiles of Idaho. Economic Development Division, Idaho Department of Commerce, Boise, ID.

Kaminski, T. and Boss, A., 1981. The gray wolf: history, pres- 
ent status, and management recommendations. Boise $\mathrm{Na}$ tional Forest, Boise, ID, $111 \mathrm{pp}$. (Unpublished.)

Kaminski, T. and Hansen, J., 1984. Wolves of central Idaho. Montana Cooperative Wildlife Research Unit, Missoula, MT, 197 pp. (Unpublished.)

Keiter, R.B. and Holscher, P.K., 1990. Wolf recovery under the Endangered Species Act: a study in contemporary Federalism. Public Land Law Rev., 11: 19-52.

Kellert, S.R., 1985. Public perceptions of predators, particularly the wolf and coyote. Biol. Conserv., 31: 167-189.

Koth, B., Lime, D.W. and Vlaming, J., 1990. Effects of restoring wolves on Yellowstone area big game and grizzly bears: opinions of fifteen North American experts. In: Yellowstone National Park, US Fish and Wildlife Service, University of Wyoming, University of Idaho, Interagency Grizzly Bear Study Team, and University of Minnesota Cooperative Park Studies Unit (Editors), Wolves for Yellowstone? A Report to the United States Congress. Vol. II. Research and Analysis, National Park Service, Yellowstone National Park, WY, pp. 1-5 to 1-58.

Laufer, J.R. and Jenkins, P.T., 1989. Historical and present status of the gray wolf in the Cascade Mountains of Washington. Northwest Environ. J., 5: 313-327.

Lopez, B.H., 1978. Of Wolves and Men. Charles Scribner's Sons, New York, 309 pp.

Mech, L.D., 1970. The Wolf: The Ecology and Behavior of an Endangered Species. The Natural History Press, Garden City, NY, 384 pp.

Mech, L.D., 1991. Returning the wolf to Yellowstone. In: R.B. Keiter and M.S. Boyce (Editors), The Greater Yellowstone Ecosystem: Redefining America's Wilderness Heritage. Yale University Press, New Haven, CT, pp. 309-322.

Montana Agricultural Statistics Service, 1992. Montana Agricultural Statistics: Historic State Series. Montana Department of Agriculture and US Department of Agriculture National Agricultural Statistics Service, Helena, MT, $128 \mathrm{pp}$.

Mussehl, T.W. and Howell, F.W. (Editors), 1971. Game management in Montana. Montana Fish and Game Department, Helena, MT, 238 pp.

Nowak, R.M., 1983. A perspective on the taxonomy of wolves in North America. In: L.N. Carbyn (Editor), Wolves in Canada and Alaska: Their Status, Biology, and Management. Rep. Ser. No. 45, Canadian Wildlife Service, Ottawa, Canada, pp. 10-19.

Oakley, G., 1986. Historic review. In: Wolves in American Culture Committee, Boise, ID (Editor), WOLF! A Modern Look. Northword Press, Ashland, WI, pp. 1-7.

Pletscher, D.H., Ream, R.R., Demarchi, R., Brewster, W.G. and Bangs, E.E., 1991. Managing wolf and ungulate populations in an international ecosystem. Trans. North Am. Wildl. Nat. Resour. Conf., 56: 539-549.

Ream, R.R. and Mattson, U.I., 1982. Wolf status in the northern Rockies. In: F.H. Harrington and P.C. Paquet (Editors), Wolves of the World: Perspectives of Behavior, Ecology, and Conservation. Noyes Publications, Park Ridge, NJ, pp. 362-381.

Ream, R.R., Fairchild, M.W., Boyd, D.K. and Blakesley, A.J., 1989. First wolf den in western U.S. in recent history. Northwest. Nat., 70: 39-40.
Ream, R.R., Fairchild, M.W., Boyd, D.K. and Pletscher, D.H., 1991. Population dynamics and home range changes in a colonizing wolf population. In: R.B. Keiter and M.S. Boyce (Editors), The Greater Yellowstone Ecosystem: Redefining America's Wilderness Heritage. Yale University Press, New Haven, CT, pp. 349-366.

Schullery, P. and Whittlesey, L., 1992. The documentary record of wolves and related wildlife species in the Yellowstone National Park area prior to 1882. In: J.D. Varley and W.G. Brewster (Editors), Wolves for Yellowstone? A Report to the United States Congress. Vol. IV. Research and Analysis, National Park Service, Yellowstone National Park, WY, pp. 1-3 to 1-174.

Tompa, F.S., 1983. Status and management of wolves in British Columbia. In: L.N. Carbyn (Editor), Wolves in Canada and Alaska: Their Status, Biology, and Management. Rep. Ser. No. 45, Canadian Wildlife Service, Ottawa, pp. 20-24.

Tucker, P. and Pletscher, D.H., 1989. Attitudes of hunters and residents toward wolves in northwestern Montana. Wildl. Soc. Bull., 17: 509-514.

Tucker, P.A, Davis, D.L. and Ream, R.R., 1990. Wolves: identification, documentation, population monitoring and conservation considerations. Northern Rockies Natural Resources Center, National Wildlife Federation. Missoula, MT, 27 pp.

US Fish and Wildlife Service, 1987. Northern Rocky Mountain Wolf Recovery Plan. US Fish and Wildlife Service, Denver, CO, 119 pp.

US Fish and Wildlife Service, 1993. Analysis of public comments on reintroduction of the gray wolf to Yellowstone National Park. US Fish and Wildlife Service, Helena, MT, 15 pp. (Unpublished.)

Varley, J.D. and Brewster, W.G. (Editors), 1992. Wolves for Yellowstone? A Report to the United States Congress, Vol. IV. Research and Analysis, National Park Service, Yellowstone National Park, WY, 750 pp.

Wayne, R.K., Lehman, N., Allard, M.W. and Honeycutt, R.L., 1992. Mitochondrial variability of the gray wolf: genetic consequences of population decline and habitat fragmentation. Conserv. Biol., 6: 559-569.

Weaver, J., 1978. The wolves of Yellowstone. Nat. Resour. Rep. No. 14, US Department of Interior, National Park Service, Washington, DC, $38 \mathrm{pp}$.

Wyoming Department of Administration and Fiscal Control, 1987. Wyoming Data Handbook. Wyoming Department of Administration and Fiscal Control, Division of Research and Statistics, Cheyenne, WY, $237 \mathrm{pp}$.

Yellowstone National Park, US Fish and Wildlife Scrvice, University of Wyoming, University of Idaho, Interagency Grizzly Bear Study Team and University of Minnesota Cooperative Park Studies Unit (Editors), 1990. Wolves for Yellowstone? A Report to the United States Congress. Vol. II. Research and Analysis, National Park Service, Yellowstone National Park, WY, 586 pp.

Young, S.P., 1944. The wolves of North America. Part 1: Their history, life habits, economic status, and control. In: S.P. Young and E.A. Goldman, The Wolves of North America. Dover Publications, New York, pp. 1-385. 